\title{
Dissociation of oocyte nuclear and cytoplasmic maturation by the addition of insulin in cultured bovine antral follicles
}

\author{
A A Fouladi-Nashta and K H S Campbell ${ }^{1}$ \\ Roslin Institute, Roslin, Midlothian, Edinburgh EH13 9HN, UK and ${ }^{1}$ School of Biosciences, University \\ of Nottingham, Sutton Bonington, Loughborough, Leicestershire LE12 5RD, UK
}

Correspondence should be addressed to A A Fouladi-Nashta; Email: ali.fouladi-nashta@nottingham.ac.uk

A A Fouladi-Nashta is now at School of Biosciences, University of Nottingham, Sutton Bonington, Loughborough, Leicestershire LE12 5RD, UK

\begin{abstract}
Follicles of 4-8 $\mathrm{mm}$ in diameter were dissected from ovaries and cultured in Waymouth culture medium in the presence or absence of insulin $(5 \mu \mathrm{g} / \mathrm{ml})$ at $39^{\circ} \mathrm{C}$ in a humidified atmosphere of $45 \% \mathrm{O}_{2}, 5 \% \mathrm{CO}_{2}$ and $50 \% \mathrm{~N}_{2}$ for $24 \mathrm{~h}$. Following follicle culture, the oocytes were collected and examined for developmental potential, total protein profile and ultrastructural aspects. Oocytes aspirated directly from follicles of the same size were used as controls. Addition of insulin to the follicle culture medium significantly reduced expression of the low molecular weight insulin-like growth factor-binding proteins (IGFBPs) in the follicular fluid, and significantly reduced the cleavage rate of subsequently matured and fertilised oocytes (0.52 vs 0.61). However, there were no differences in the proportion of cleaved embryos which developed to the blastocyst stage $(0.30$ vs 0.28$)$, nor embryo quality as assessed by total cell number $(137 \pm 8.53$ vs $124.6 \pm 6.95)$. The total protein profiles of immature oocytes recovered after $24 \mathrm{~h}$ of follicle culture were compared by PAGE. There were marked differences between the two groups, unmatured oocytes recovered from the insulin-positive follicle group showed a protein pattern similar to that of matured oocytes. In addition, examination of ultrastructural features by transmission electron microscopy indicated that oocytes from follicles cultured in the presence of insulin undergo many of the cytoplasmic changes associated with oocyte maturation. In conclusion, follicle culture in the presence of insulin is beneficial for follicular survival and significantly reduces cleavage but has no detrimental effects on the development of cultured embryos. However, many of the cytoplasmic changes associated with oocyte maturation occur prior to the induction of nuclear maturation.

Reproduction (2006) 131 449-460
\end{abstract}

\section{Introduction}

The growth and development of ovarian follicles, oocytes and embryos depend upon the spatial and temporal expression of specific genes and on a continuous supply of energy, hormones and growth factors. Insulin, which is primarily involved in the regulation of glucose concentration in the circulation, also regulates cell growth and development in a wide variety of cell types (Starus 1981, Hsueh et al. 1984). The importance of insulin as a regulator of ovarian function was revealed in patients with altered insulin concentrations. Insulin-dependent diabetes mellitus in women is commonly accompanied by ovarian hypo-function and amenorrhea, whilst hyper-insulinaemia is associated with ovarian hyperstimulation and hyperandrogenism (Poretsky \& Kalin 1987, Poretsky 1991, Fulghesu et al. 1997). Mouse models of maternal hypoinsulinaemia and hyperglycaemia produce oocytes and developing ovarian follicles of smaller sizes, reduced percentage of germinal vesicle breakdown and an increased occurrence of apoptosis (Chang et al. 2005). In cattle, high insulin concentrations in non-lactating heifers were associated with increased numbers of small follicles (<4 mm) (Gong et al. 1993a) and an increased response to superovulatory treatment (Gong et al. 1993b).

In vitro, insulin has repeatedly been reported to stimulate proliferation and steroidogenesis of granulosa and theca cells (Campbell et al. 1995, Duleba et al. 1997) and is routinely included in tissue and cell culture media. In porcine (May et al. 1980) and human (Hill \& Osteen 1992) ovarian tissue, insulin stimulates granulosa cell progesterone secretion and granulosa cell luteinisation (Channing et al. 1976) and induces granulosa cell luteinising hormone (LH)/human chorionic gonadotrophin (hCG) receptors (May et al. 1980). It also increases rat granulosa cell oestrogen and progestin production in response to follicle-stimulating hormone (FSH) (Davoren \& Hsueh 1984).

A role for insulin in oocyte maturation has been described. Insulin induced meiotic maturation in Xenopus 
laevis oocytes. Tsafriri \& Channing (1975) demonstrated that insulin stimulates maturation of pig oocytes beyond first metaphase and extrusion of the first polar body. Subsequently, Lessman \& Schuetz (1981) reported that insulin facilitates germinal vesicle breakdown in leopard frogs (Rana pipiens). In cattle, mRNA encoding receptor for insulin has been detected at all embryonic stages from the one-cell zygote to the blastocyst (Schultz et al. 1992). However, insulin does not improve bovine oocyte maturation (Betteridge et al. 1989) and has no effect on the fertilisation rate or subsequent development (Stubbings et al. 1990). In the mouse, protein synthesis increases in the presence of insulin at the compacted morulae stage of development (Rao et al. 1990, Kaye et al. 1992) when the insulin receptor appears (Harvey \& Kaye 1988).

The insulin-like growth factors (IGFs) are small proteins, structurally related to proinsulin, that stimulate growth and differentiation of a wide variety of cell types (Jones \& Clemmons 1995). In the circulation and body fluids, IGFs are complexed with specific binding proteins (IGFBPs) and association of IGFs with their binding proteins in the circulation prolongs their half-life by decreasing their clearance rate (Jones \& Clemmons 1995).

The IGFBP content of ovarian follicular fluid from a number of species has been examined using Western ligand blots and immunoblots. For example, in the cow, binding proteins of molecular mass $40-44 \mathrm{kDa}$ (IGFBP-3), $34 \mathrm{kDa}$ (IGFBP-2), 29-27 kDa (IGFBP-5) and $22 \mathrm{kDa}$ (IGFBP-4) have been identified (Echternkamp et al. 1994). The actions of IGFs in ovarian cell cultures have been shown to be inhibited by IGFBPs (Mason et al. 1992, Monget et al. 1993). A decrease in follicular IGFBP production would therefore be expected to increase the biological activity of locally produced IGF and thus increase the sensitivity of the follicle to gonadotrophins. The observed changes in the concentration of IGFBPs in follicular fluid during follicle development agree with this hypothesis and indicate that IGFBPs are key autocrine and paracrine regulators of ovarian function.

We have previously reported a system for the culture of bovine intact antral follicles in vitro (Fouladi-Nashta et al. 1998). Oocytes recovered following $24 \mathrm{~h}$ of follicle culture remained at the germinal vesicle (GV) stage and gave a significantly greater frequency of development compared with oocytes aspirated from fresh follicles, following subsequent maturation, fertilisation and culture. Insulin is generally added to tissue culture including ovarian follicles as a survival/mitogenic factor in high concentrations. Use of supra-physiological concentrations of insulin may be beneficial for the survival of ovarian follicular somatic cells, but may have a detrimental effect on oocyte quality and development. The aims of the experiments reported here were to elucidate the effects of addition of insulin to the follicle culture medium on follicular survival, via the evaluation of embryonic development and the quality of oocytes following $24 \mathrm{~h}$ of follicle culture. The effect of insulin on the ultrastructure of immature oocytes derived following follicle culture in the presence of insulin was examined. In addition, the effects of insulin on IGFBP and total protein profiles in follicles and oocytes were investigated.

\section{Materials and Methods}

All chemicals and reagents were purchased from Sigma (Poole, Dorset, UK) unless otherwise stated.

\section{Isolation and culture of antral follicles}

Ovaries were obtained from local abattoirs and maintained at $28-35{ }^{\circ} \mathrm{C}$ during transport to the laboratory $(1-2 \mathrm{~h}$ ). Using a pair of scissors and forceps, follicles of $4-8 \mathrm{~mm}$ diameter were dissected from the surrounding connective tissues and cultured as previously described (FouladiNashta et al. 1998). Briefly, non-atretic follicles were selected on the basis of morphological criteria, including translucency, lack of free particles in the antrum and the presence of blood vessels in the follicular wall (Kruip \& Dieleman 1982).

Selected follicles were cultured in six-well culture dishes fitted with netwell inserts of $500 \mu \mathrm{m}$ pore diameter containing Waymouth medium MB752/1 (Invitrogen, Paisley, Strathclyde, UK) supplemented with $0.23 \mathrm{mM}$ pyruvic acid, $50 \mathrm{mg} / \mathrm{l}$ streptomycin sulphate, $75 \mathrm{mg} / \mathrm{l}$ penicillin G

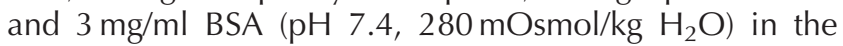
presence or absence (control) of $5 \mu \mathrm{g} / \mathrm{ml}$ insulin. A gaseous atmosphere of $45 \% \mathrm{O}_{2}, 50 \% \mathrm{~N}_{2}$ and $5 \% \mathrm{CO}_{2}$ was used according to Moor et al. (1973). Before use, the culture medium was placed in an anaerobic jar which was gassed for $5 \mathrm{~min}$, sealed and warmed to $39^{\circ} \mathrm{C}$ in an incubator. After transferring the follicles into the culture dishes, they were replaced in the anaerobic jar which was gassed for $5 \mathrm{~min}$ before being sealed and returned to the incubator.

\section{Oocyte collection}

Cumulus-oocyte complexes (COCs) were aspirated from follicles $4-8 \mathrm{~mm}$ in diameter using a $10 \mathrm{ml}$ syringe fitted with a hypodermic needle $(1.2 \mathrm{~mm}$ internal diameter). The aspirated follicular fluid was placed into sterile universal containers (Nunc, Rosklide, Denmark), in a warm air chamber $\left(39^{\circ} \mathrm{C}\right)$ and allowed to settle for $10-15 \mathrm{~min}$. The majority of the follicular fluid was then removed by surface aspiration and the remaining follicular material diluted with an equal volume of dissection medium (TCM199 with Earl's salts (Invitrogen, Paisley, UK) $75.0 \mathrm{mg} / \mathrm{l}$ kanamycin, $7.08 \mathrm{~g} / \mathrm{l}$ Hepes $(\mathrm{pH} 7.8$, osmolarity $279 \mathrm{mOsmol} / \mathrm{kg} \mathrm{H}_{2} \mathrm{O}$ ] supplemented with $10 \%$ fetal calf serum (FCS). The diluted follicular fluid was transferred into an $85 \mathrm{~mm}$ Petri dish (Bibby Sterilin, Stone, UK) and examined for COCs under a dissecting microscope.

Oocytes from follicle culture treatments were collected after opening the follicles with forceps. After $24 \mathrm{~h}$ of follicle culture, COCs from both groups $(n=106$ in insulin-positive and $n=98$ in insulin-negative groups) were 
collected and washed in dissection medium as previously described.

\section{Oocyte maturation}

COCs isolated following $24 \mathrm{~h}$ of follicle culture were washed twice in dissection medium and transferred into $500 \mu \mathrm{l}$ pre-gassed maturation medium (TCM199 with Earl's salts, $75 \mathrm{mg} / \mathrm{l}$ kanamycin, $4.75 \mathrm{~g} / \mathrm{l}$ Hepes, $2.29 \mathrm{~g} / \mathrm{l}$ $\mathrm{NaHCO}_{3}\left(\mathrm{pH} 7.8\right.$, osmolarity $280 \mathrm{mOsmol} / \mathrm{kg} \mathrm{H} \mathrm{H}_{2} \mathrm{O}$ ) supplemented with $0.006 \mathrm{IU} / \mathrm{ml} \mathrm{FSH} / \mathrm{LH}$ (Pergonal; Serono Laboratories, Herts, UK) and 10\% FCS in $35 \mathrm{~mm}$ tissue culture dishes. COCs were then incubated in a humidified atmosphere of $5 \% \mathrm{CO}_{2}$ in air at $39^{\circ} \mathrm{C}$ for $24 \mathrm{~h}$.

\section{In vitro fertilisation}

In vitro matured oocytes were fertilised as previously described (Fouladi-Nashta et al. 1998). Briefly, COCs were gently pipetted in order to remove adhering granulosa cells and break up aggregated COCs. Disaggregated COCs were then washed once in oocyte wash medium containing $6.8 \mathrm{~g} / \mathrm{l} \mathrm{NaCl}, 0.23 \mathrm{~g} / \mathrm{l} \mathrm{KCl}, 168 \mathrm{mg} / \mathrm{l} \mathrm{NaHCO}$, $47 \mathrm{mg} / \mathrm{l} \quad \mathrm{Na}_{2} \mathrm{HPO}_{4}, 4.8 \mathrm{~g} / \mathrm{l}$ Hepes, $75 \mathrm{mg} / \mathrm{l}$ kanamycin monosulphate, $11 \mathrm{mg} / \mathrm{l}$ pyruvic acid, $6 \mathrm{~g} / \mathrm{l}$ BSA, $1.86 \mathrm{ml} / \mathrm{l}$ $60 \%$ syrup lactic acid, $100 \mathrm{mg} / \mathrm{l} \mathrm{MgCl}_{2} .6 \mathrm{H}_{2} \mathrm{O}, 0.84 \mathrm{~g} / \mathrm{l}$ $\mathrm{CaCl}_{2} .2 \mathrm{H}_{2} \mathrm{O}\left(\mathrm{pH} 7.4\right.$, osmolarity $\left.282 \mathrm{mOsmol} / \mathrm{kg} \mathrm{H}_{2} \mathrm{O}\right)$ and transferred into $45 \mu \mathrm{l}$ microdrops of fertilisation medium (five to ten oocytes/drop) containing sperm $\left(1.5 \times 10^{6} / \mathrm{ml}\right)$ and maintained for $24 \mathrm{~h}$ at $39^{\circ} \mathrm{C}$ in a humidified incubator in $5 \% \mathrm{CO}_{2}$ in air.

\section{In vitro embryo culture}

At $46-48 \mathrm{~h}$ after co-incubation of the spermatozoa and oocytes, cleaved embryos with at least four cells were selected, washed twice in a Hepes-buffered synthetic oviductal fluid (SOF) medium and transferred to $20 \mu \mathrm{l}$ droplets $(5 \mu \mathrm{l} / \mathrm{embryo})$ of SOF medium (Thompson et al. 1991) supplemented with $4 \mathrm{mg} / \mathrm{ml}$ Pentex crystalline BSA (Bayer, Elkhart, Germany) overlaid with mineral oil. Embryo culture was carried out in $35 \mathrm{~mm}$ cell culture dishes at $39^{\circ} \mathrm{C}$, in a humidified incubator with a gaseous atmosphere of $5 \% \mathrm{CO}_{2}$ and $5 \% \mathrm{O}_{2}$.

\section{Total cell counting}

Blastocyst stage embryos were incubated for $15 \mathrm{~min}$ in dissection medium containing $5 \mu \mathrm{g} / \mathrm{ml}$ bisbenzimide (Hoechst 33258; Sigma). The embryos were then placed onto clean glass slides in $3 \mu \mathrm{l}$ drops of diazabicyclo (2.2.2) octane (DABCO; Sigma) and secured with $22 \mathrm{~mm}^{2}$ coverslips. Counting took place using an inverted, differential interference contrast microscope fitted with epifluorescence (Nikon, Garden City, NY, USA).

\section{Transmission electron microscopy of oocyte ultrastructure}

COCs were collected following $24 \mathrm{~h}$ of follicle culture in the presence $(n=18)$ or absence $(n=18)$ of insulin. A proportion of oocytes from each group were matured in vitro ( $n=6$ in each treatment). Immature and in vitro matured oocytes were processed for electron microscopy using a modification of the protocol described by Hyttel \& Madsen (1987). Briefly COCs were fixed in $3 \%$ glutaradehyde in $0.1 \mathrm{M}$ Millonigs buffer (Sigma; $\mathrm{pH} 7.4$ ), for $1 \mathrm{~h}$ at $4{ }^{\circ} \mathrm{C}$, then washed three times each for $20 \mathrm{~min}$ in $0.2 \mathrm{M}$ buffer and post-fixed in $1 \% \mathrm{OsO}_{4}$ in $0.1 \mathrm{M}$ buffer for $1 \mathrm{~h}$ at $4{ }^{\circ} \mathrm{C}$. The oocytes were then washed in distilled water for $30 \mathrm{~min}$, placed in $0.5 \%$ uranyl acetate (TAAB Laboratories, Reading, UK) for $2 \mathrm{~h}$, and dehydrated in ascending concentrations of ethanol, cleared in inhibisol (1.1.1.trichloroethane), and impregnated and embeded in Araldite. Ultrathin sections ( $300 \AA)$ of oocytes were cut perpendicular to the plating surface. Oocyte sections were stained for 3 min with uranyl acetate (25\% uranyl acetate in $50 \%$ ethanol; Watson 1958) and $7 \mathrm{~min}$ with lead citrate (Reynolds 1963). Ultra-structural observations were made using a Philips EM300 electron microscope (Eindhoven, The Netherlands).

\section{Total protein profile of oocytes}

\section{Oocyte preparation}

Non-mature oocytes (total of 54 oocytes in three replicate cultures) were collected following $24 \mathrm{~h}$ of follicle culture in the presence $(n=27)$ or absence $(n=27)$ of insulin, transferred into $500 \mu \mathrm{l}$ drops of dissection medium containing 300 units/ml hyaluronidase (Sigma) and incubated at $39^{\circ} \mathrm{C}$ for $15 \mathrm{~min}$. After incubation, the oocytes were transferred into dissection medium and the cumulus cells removed by repeated pipetting. Denuded oocytes were placed into $1.5 \mathrm{ml}$ Eppendorf tubes containing $15 \mu \mathrm{l}$ sample buffer. The oocytes were then lysed by multiple rapid freeze-thaw cycles in liquid nitrogen and methanol respectively. The prepared samples were stored at $-20^{\circ} \mathrm{C}$ until PAGE analysis.

\section{One dimensional SDS-PAGE}

A $6 \%$ acrylamide gel for protein separation and $4 \%$ stacking gel were freshly prepared in a mini-protean II (BioRad, Hemel Hempstead, UK). Prepared samples were thawed on ice, boiled for $3 \mathrm{~min}$ to denature the proteins and then stored on ice until loading onto the gel. Molecular weight markers (29000-116000) were run on each gel to ascertain the molecular weight in $\mathrm{kDa}$ of the separated proteins. A total of five oocytes were loaded/sample well. The gel was run for $6 \mathrm{~h}$ at a constant voltage of $200 \mathrm{~V}$. After running, gels were fixed in a solution of $10 \%$ glacial acetic acid and $40 \%$ methanol in distilled water for at least $1 \mathrm{~h}$. 


\section{Silver staining}

After fixation, the gels were silver stained using a modification of the method described by Blum et al. (1987). Briefly, the gels were washed twice for $20 \mathrm{~min}$ in doubledistilled water (DDW) followed by a 20-min dehydration in $50 \%$ ethanol and pretreated in a $0.2 \mathrm{mg} / \mathrm{ml}$ solution of $\mathrm{Na}_{2} \mathrm{~S}_{2} \mathrm{O}_{3} .5 \mathrm{H}_{2} \mathrm{O}(\mathrm{BDH}$, Poole, Dorset, UK) for $1 \mathrm{~min}$. They were then passed through three quick washes in DDW and placed into a solution containing $2 \mu \mathrm{g} / \mathrm{ml}$ silver nitrate (BDH) and $0.75 \mu \mathrm{l} / \mathrm{ml} \mathrm{36 \%}$ formaldehyde (TAAB Laboratories) for $30 \mathrm{~min}$ to allow silver impregnation. After staining, the gels were given two quick washes in DDW and the protein bands were visualised in a development solution containing $60 \mathrm{mg} / \mathrm{ml} \mathrm{Na}_{2} \mathrm{CO}_{3}(\mathrm{BDH}), 0.5 \mu \mathrm{l} / \mathrm{ml} \mathrm{36 \%}$ $\mathrm{HCHO}$ and $0.5 \mu \mathrm{g} / \mathrm{ml} \mathrm{Na} \mathrm{Na}_{2} \mathrm{O}_{3} .5 \mathrm{H}_{2} \mathrm{O}$ for $3-4 \mathrm{~min}$. Development was monitored visually and stopped by placing the gel into a solution containing $18.6 \mathrm{mg} / \mathrm{ml}$ EDTA (Sigma) and $0.2 \mathrm{mg} / \mathrm{ml}$ thiomersol for $30 \mathrm{~min}$. The gels were then washed in DDW for $30 \mathrm{~min}$ and equilibrated in a solution containing 33\% ethanol and 3\% glycerol at least for $1 \mathrm{~h}$.

\section{Analysis of IGFBP profiles}

IGFBP profiles in both follicular fluid from individual follicles cultured in the presence $(n=14$ in $2-4 \mathrm{~mm}$ and $n=8$ in $4-8 \mathrm{~mm})$ and absence of insulin $(n=12$ in $2-4 \mathrm{~mm}$ and $n=8$ in $4-8 \mathrm{~mm}$ ) and culture media were analysed by Western ligand blot. Samples of follicular fluid were diluted $\left(2 \mu \mathrm{l}\right.$ follicular fluid $+23 \mu \mathrm{l}$ distilled $\mathrm{H}_{2} \mathrm{O}$ ) and the $25 \mu \mathrm{l}$ follicular sample or $25 \mu \mathrm{l}$ culture media were mixed with $25 \mu \mathrm{l}$ Laemmli sample buffer $(10 \mathrm{ml} 0.5 \mathrm{M}$ Tris- $\mathrm{HCl}, \mathrm{pH} 6.8,10 \mathrm{ml} 10 \%$ SDS and $10 \mathrm{ml}$ glycerol,

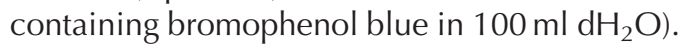

Samples were solubilised and loaded onto $12 \%(\mathrm{w} / \mathrm{v})$ non-reducing SDS-PAGE gels and electroblotted onto PVDF membrane. Non-specific binding sites on the membrane were blocked using $3 \%(\mathrm{w} / \mathrm{v})$ BSA in PBS-0.1\% $(\mathrm{v} / \mathrm{v})$ Tween 20 (blocking solution). The blot was then left overnight in $1 \%$ BSA and $0.1 \%$ Tween 20 in TS buffer $(150 \mathrm{mM} \mathrm{NaCl}, 10 \mathrm{mM}$ Tris- $\mathrm{HCl} \mathrm{pH}$ 7.4) containing $3 \times 10^{6}$ c.p.m. ${ }^{125}$ I-labelled ligand (in $20 \mathrm{ml}$ ). After labelling, the blots were washed four times, each for $30 \mathrm{~min}$, in $0.2 \%$ Nonidet P40 in TS buffer. All washing steps were performed at $4{ }^{\circ} \mathrm{C}$. The nitrocellulose was then dried and exposed to a Cronez 4 film (Sterling Diagnostic Imaging
Inc, Newark, DE, USA) for 3 days. The films were developed using an autoradiograph developer.

\section{Statistical analysis}

The data from the proportion of oocytes which cleaved after fertilisation and the proportion of cleaved embryos which became blastocysts were analysed by fitting replicates as a source of random variation in a general linear mixed model (Breslow \& Clayton 1993).

\section{Results}

\section{The developmental competence of oocytes and embryo quality}

The effects of addition of insulin to follicle culture media are summarised in Table 1 . There was a significant reduction in the proportion of cleaved embryos in the insulin-treated group as compared with the control (means \pm S.E.M.; $0.52 \pm 0.029$ vs $0.61 \pm 0.032)(P<0.05)$. However, there was no significant difference in the proportion of cleaved embryos that became blastocysts $(0.30 \pm 0.038$ in the insulin-positive group vs $0.28 \pm 0.047$ in the control group; $0.15 \pm 0.089$ vs $0.18 \pm 0.075$ of oocytes) nor in the quality of embryos between the two groups as assessed by total cell number $(137 \pm 8.53$ vs $124.6 \pm 6.95)$.

\section{Total protein profile in the oocytes}

Total protein profiles of immature oocytes (groups of five oocytes in each category) collected either directly from follicular aspiration (non-mature oocytes aspirated from fresh follicles; NM) or following follicle culture in the presence of insulin (insulin-treated follicles; FNMI) as well as the in vitro matured oocytes from these categories (24h of oocyte maturation (M) and $24 \mathrm{~h}$ of follicle culture $+24 \mathrm{~h}$ of oocyte maturation (FM)) were compared. A representative profile of total proteins in the oocytes is shown in Fig. 1. Non-matured oocytes recovered from follicle culture in the presence of insulin (immature oocytes from insulin-treated follicles; FNMI) had a remarkably different profile from both immature NM and non-mature oocytes collected after follicle culture (FNM) (insulin-negative) oocytes. This group of oocytes (insulin-positive group) showed a profile more similar to that of matured oocytes. The differences were observed either as reduction in the concentration or disappearance of protein bands such as

Table 1 Effect of addition of insulin during follicle culture on the developmental competence of the recovered oocytes. Insulin adversely reduced the cleavage $(P<0.05)$ rate but there were no differences in either the number of quality of blastocysts between the two groups. The values are presented as means \pm S.E.M.

\begin{tabular}{|c|c|c|c|c|c|}
\hline & No. of oocytes & Cleaved $(\%) *$ & Blastocysts/oocytes (\%) & Blastocysts/cleaved (\%) & Cell numbers \\
\hline Control & 98 & $61 \pm 3.28$ & $15 \pm 8.9$ & $28 \pm 4.74$ & $124.6 \pm 6.95$ \\
\hline Insulin & 106 & $52 \pm 2.92$ & $18 \pm 7.5$ & $30 \pm 3.81$ & $137.4 \pm 8.53$ \\
\hline
\end{tabular}

$* P<0.05$. 


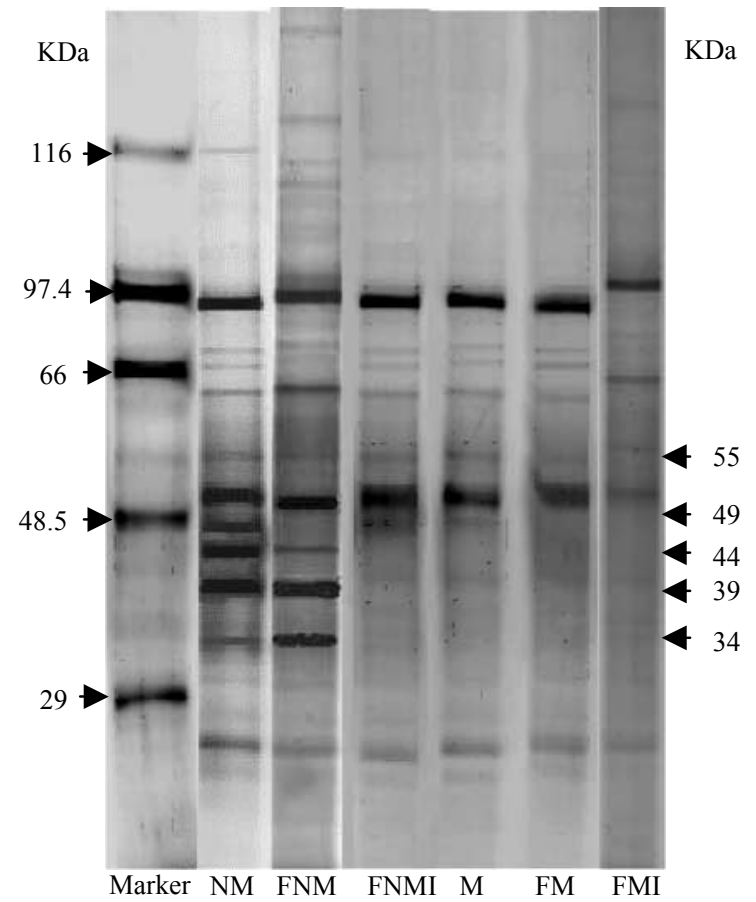

Figure 1 Effects of addition of insulin during the culture of bovine large antral follicles on total protein profile of oocytes. Immature oocyte from insulin-treated follicles (FNMI) displayed a protein profile identical to matured oocytes. There was no difference in the protein profile of oocytes after maturation. NM, non-mature oocyte aspirated from fresh follicle; FNM, non-mature oocyte collected after follicle culture; FM, $24 \mathrm{~h}$ of follicle culture $+24 \mathrm{~h}$ of oocyte maturation; $\mathrm{M}, 24 \mathrm{~h}$ of oocyte maturation; $\mathrm{FMI}, 24 \mathrm{~h}$ of follicle culture in the presence of insulin $+24 \mathrm{~h}$ of oocyte maturation.

the $34,39,42,50$ and $55 \mathrm{kDa}$ proteins that were also observed following maturation in vitro. There were no detectable differences in the total protein profile between the two groups following subsequent in vitro maturation (FM vs M). However, there was a significant reduction in the $50 \mathrm{kDa}$ protein in follicles cultured for $24 \mathrm{~h}$ in the presence of insulin $+24 \mathrm{~h}$ of oocyte maturation (FMI) oocytes.

\section{Ultrastructure of oocytes}

A total of 36 oocytes were sectioned and analysed $(n=24$ immature and 12 matured). Representative images of the oocytes from both treatments are shown in Figs 2-7. The ultrastructure of immature oocytes recovered following follicle culture in the absence of insulin and in vitro matured oocyte are shown in Figs 2 and 3 respectively. Immature oocytes were characterised by peripherally located clusters of mitochondria and cortical granules (Fig. 2). In matured oocytes, the mitochondria become evenly distributed throughout the cytoplasm and the cortical granules became individually located in the marginal area under the oocyte membrane (Fig. 3). The ultrastructure of immature oocytes recovered following $24 \mathrm{~h}$ of follicle culture in the presence of insulin is shown in Figs 4 and 5. In these oocytes, the cortical granules changed their position from being in clusters to becoming individually located in the marginal area. The mitochondria became dispersed throughout the cytoplasm. The number of vesicles reduced and these moved towards the central area. The majority of these oocytes exhibited an organellefree area under the zona pellucida. This feature was recorded in $75 \%$ of the oocytes examined $(n=9)$. The majority of the oocyte microvilli remained attached to the zona pellucida. However, some of them became terminated in the previtelline space. Similar features were observed in in vitro matured oocytes following follicle culture in the absence (Fig. 6) and presence of insulin (Fig. 7).

\section{IGFBPS}

The IGFBPs present in follicular fluid and the culture media were compared following culture of small $(2-4 \mathrm{~mm})$ - and medium $(4-8 \mathrm{~mm})$-sized follicles in the presence or absence of insulin. The control contained samples from the pool of follicular fluid collected from the aspiration of oocytes that were used for subsequent maturation. Follicular fluid and culture media collected from the culture of individual follicles cultured in the presence $(n=22$ follicles) and absence ( $n=20$ follicles) of insulin were analysed by Western blotting ( $n=5$ Western blots repeats). A representative profile of IGFBPs is shown in Fig. 8. Whilst the control group showed moderate amounts of IGFBPs, there were major qualitative differences in both culture medium and follicular fluid between the insulin-positive and control groups. In insulin-treated follicles two strong bands corresponding to IGFBP-4 (19-22 kDa) and -2 (29-34 kDa) disappeared in both the follicular fluid and the culture media of $4-8 \mathrm{~mm}$ diameter follicles. In contrast, smaller follicles retained the same pattern of IGFBPs.

\section{Discussion}

The results of the present studies have demonstrated that the presence of insulin has a number of effects on the immature or GV stage oocyte, including changes in protein profile and ultrastructure. In addition, following subsequent maturation and fertilisation, a decrease in cleavage rates was observed in insulin-treated oocytes. Transcripts for the receptors of insulin have been detected at all developmental stages of preimplantation bovine embryos (Watson et al. 1994). Insulin stimulates both amino acid uptake and protein synthesis (Harvey \& Kaye 1988, Kaye et al. 1992) in mouse preimplantation embryos. We observed significant quantitative changes in the total protein profile of the immature oocytes following follicle culture in the presence of insulin. For example, proteins with molecular weights of 34, 39, 42 and $50 \mathrm{kDa}$ were decreased or became undetectable. The involvement of proteins of these molecular weights has previously been documented in a number of different species (Cicirelli et al. 1988, Mutter et al. 1988, Naz et al. 2001). The $50 \mathrm{kDa}$ protein that was reduced in FMI oocytes may be the oocyte 

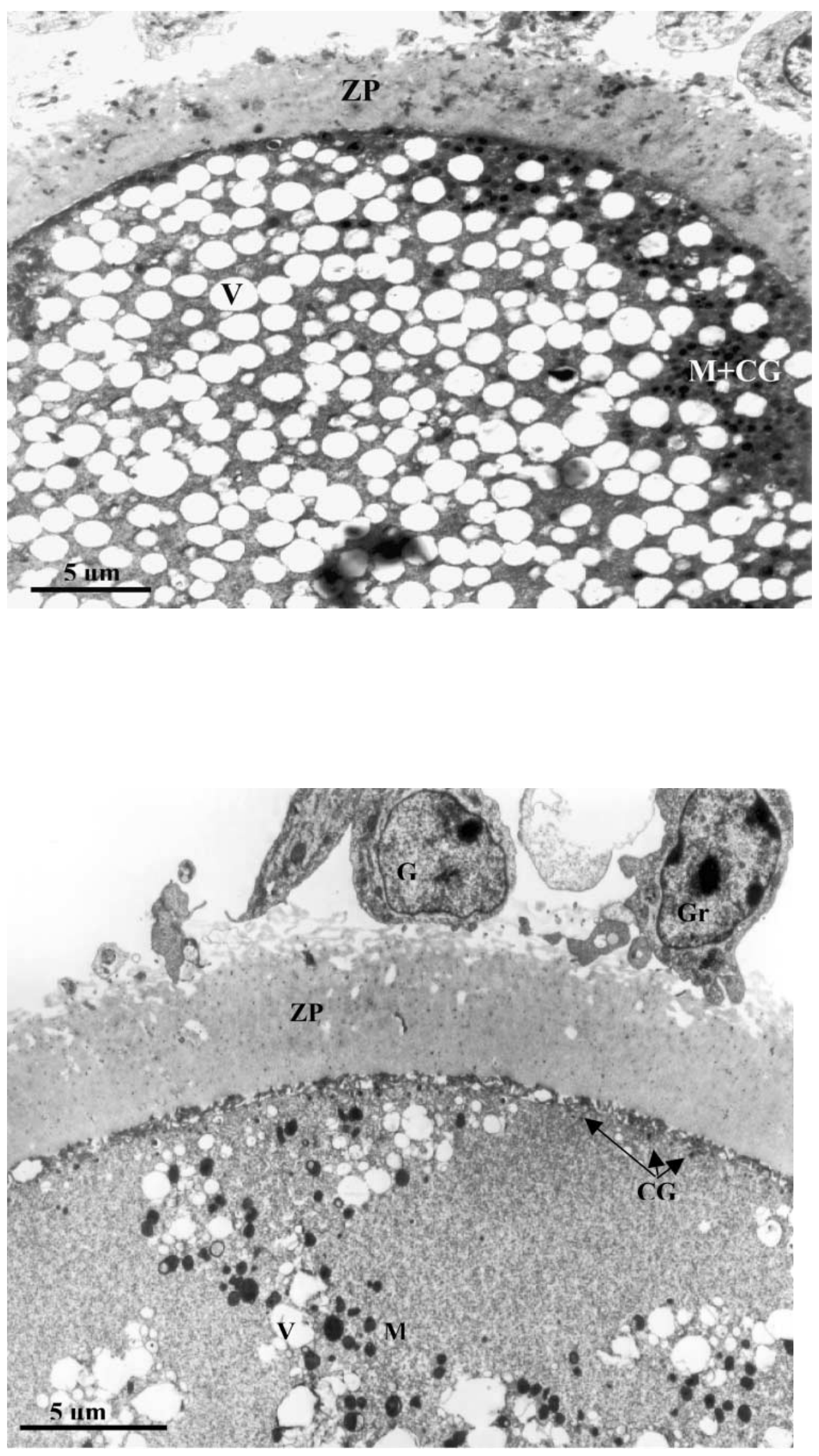

Figure 2 Electron micrograph showing part of an immature oocyte following $24 \mathrm{~h}$ of follicle culture (FNM) in the control group. Note the clusters of mitochondria $(M)$ and cortical granules (CG) located peripherally and distribution of fat vesicles $(\mathrm{V})$ throughout the cytoplasm. ZP, zona pellucida.
Figure 3 Electron micrograph showing part of an in vitro matured control oocyte. Note relocation of the mitochondria $(M)$ throughout the cytoplasm and location of the cortical granules (CG) in the marginal area. The number of fat vesicles $(\mathrm{V})$ has reduced. ZP, zona pellucida; Gr, granulosa cell. 


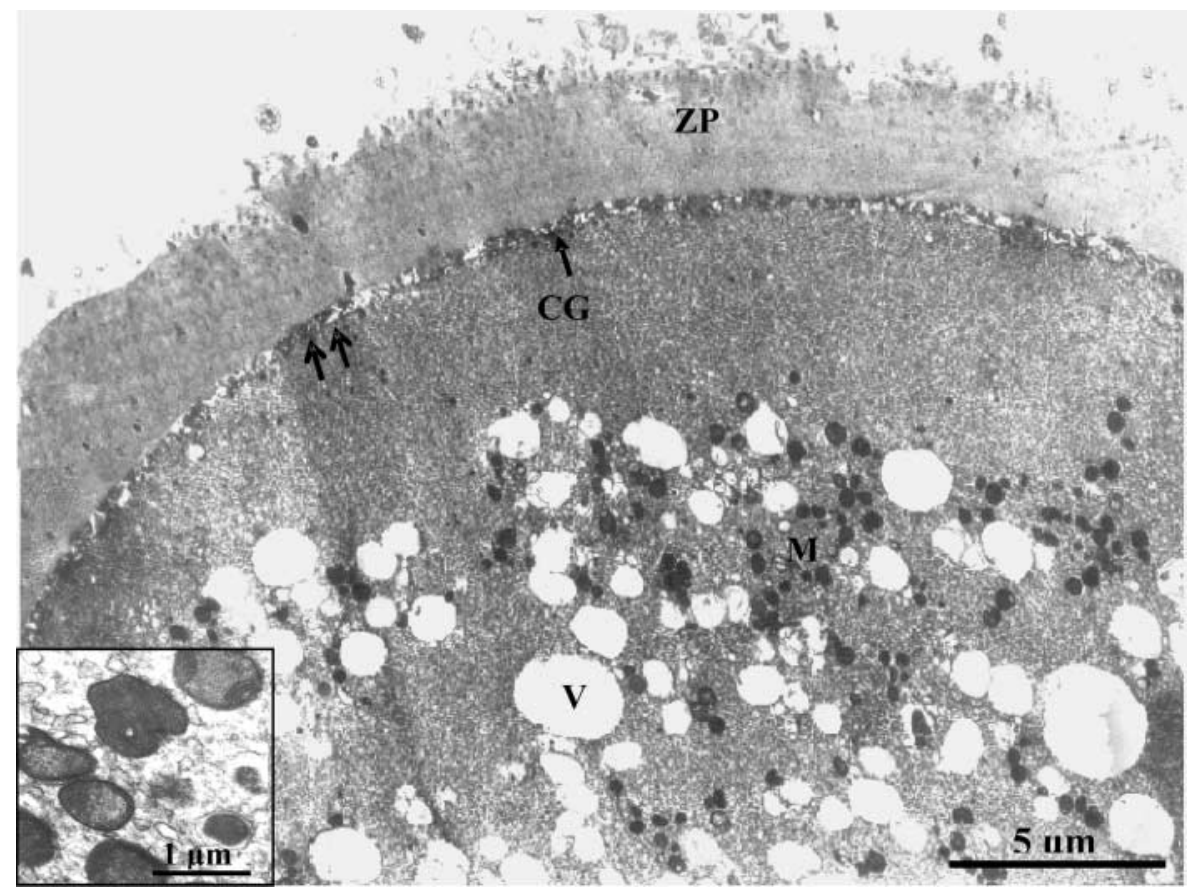

Figure 4 Electron micrograph showing part of an immature oocyte following culture of large antral follicles in the presence of insulin. The oocyte gained the features of a matured oocyte. The mitochondria (M) became evenly distributed throughout the cytoplasm (see inset). Some of the small vesicles fused together and formed giant vesicles $(\mathrm{V})$. Note the organelle-free area in the marginal area. The cortical granules (CG) became located individually in the margin of oocyte. The inset shows high magnification of a group of mitochondria. ZP, zona pellucida.

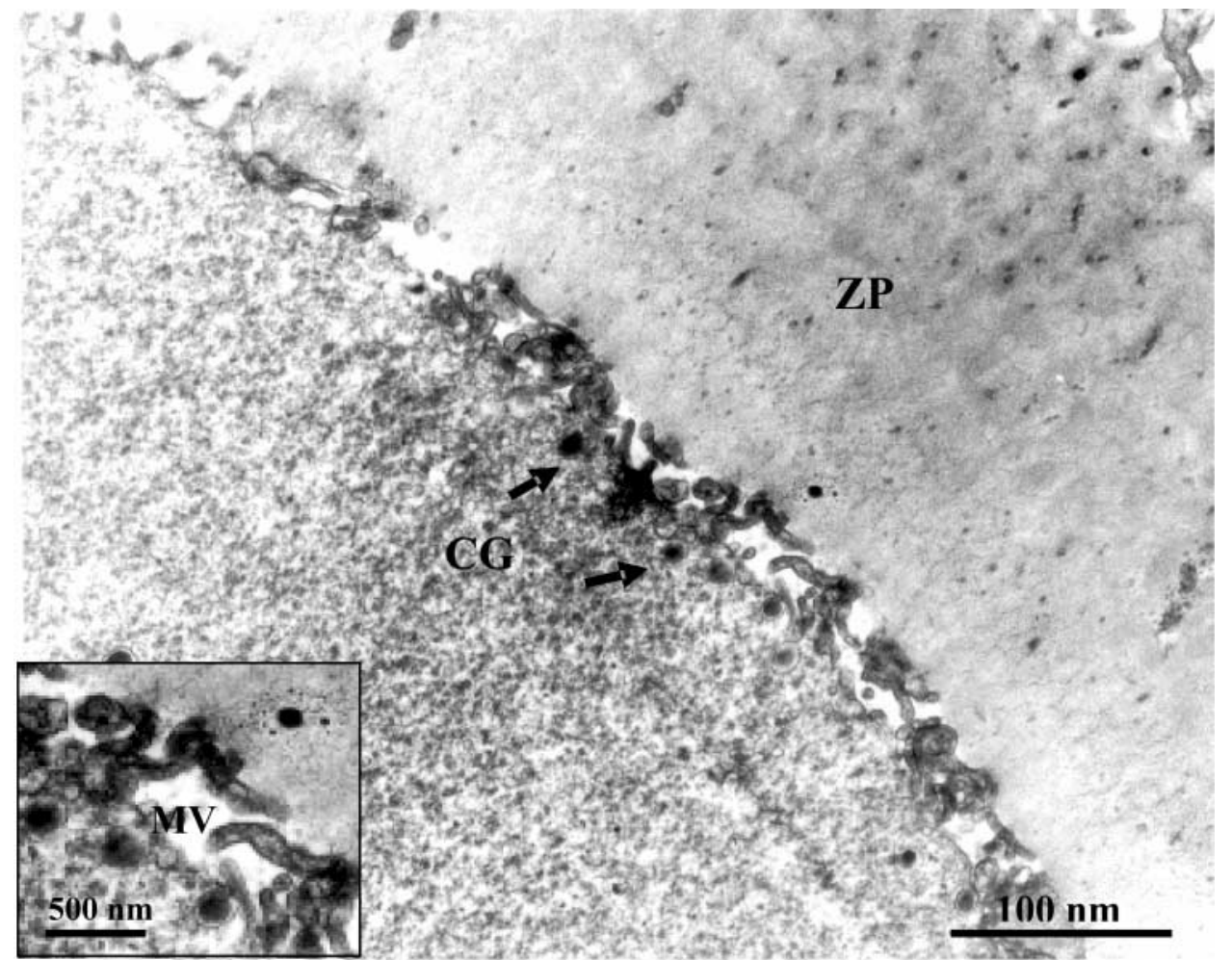

Figure 5 Electron micrograph showing part of an immature oocyte following culture of large antral follicles in the presence of insulin. Cortical granules (CG) are located individually in the margin of oocyte. Many of the microvilli are disconnected and terminate in the perivitelline space (see inset) but some of them still penetrated into the zona pellucida (ZP). MV, microvilli. membrane antigen that is important for binding to sperm during fertilisation (Naz et al. 2001). Reduction in the expression of this protein may have contributed to the lower cleavage rate of the FMI oocytes.

There is a limited number of studies on the effects of insulin on oocyte maturation and preimplantation bovine embryo development. Over-stimulation of IGF-I (Armstrong et al. 2001) and probably insulin (Armstrong et al. 2003) is detrimental to follicle and oocyte development. In mice, high concentrations of IGF-I and insulin induced a down-regulation of the IGF-I receptor in blastocysts, with a subsequent decrease in signalling of IGF-I 


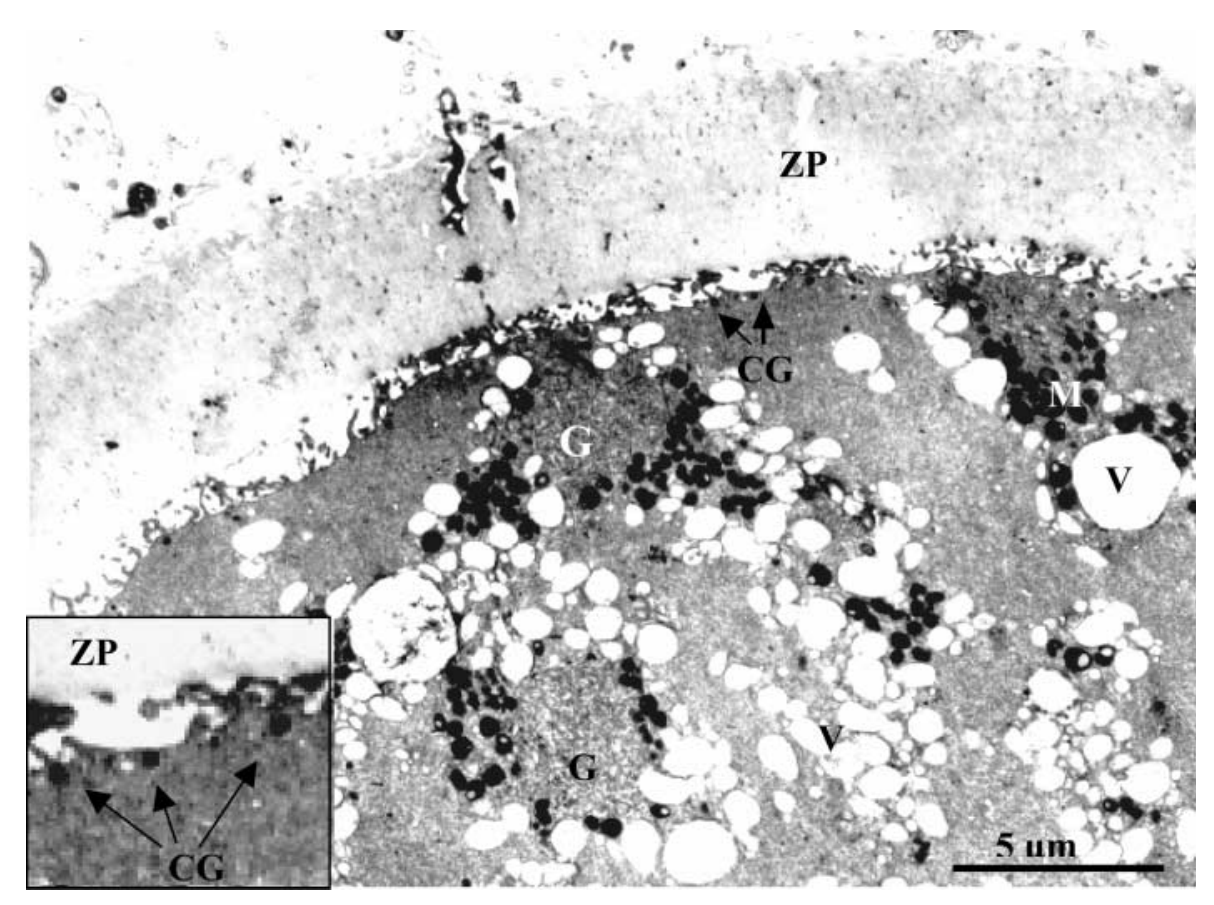

Figure 6 Electron micrograph showing part of an in vitro matured oocyte following follicle culture in the absence of insulin. Note the relocation of mitochondria (M) throughout the cytoplasm and relocation of the cortical granules (CG) in the marginal area (see inset). The number of fat vesicles $(\mathrm{V})$ has reduced. $\mathrm{ZP}$, zona pellucida; G, Golgi apparatus. receptor-associated pathways (Chi et al. 2000). This decrease in IGF-I receptor reduced glucose uptake and triggered apoptosis. In addition, women with polycystic ovary syndrome exhibit elevated concentrations of insulin and IGF-I and experience increased pregnancy losses (Tulppala et al. 1993, Zephne et al. 2004, Dumesic et al.
2005). A threshold may exist at which the level of growth hormone, IGF-I or insulin goes from being beneficial to detrimental on oocyte and embryo development. Matsui et al. (1997) reported that insulin at concentrations of $0.5-10 \mu \mathrm{g} / \mathrm{ml}$ had a beneficial effect on the rate of development to the morula stage on day 5 of embryo culture

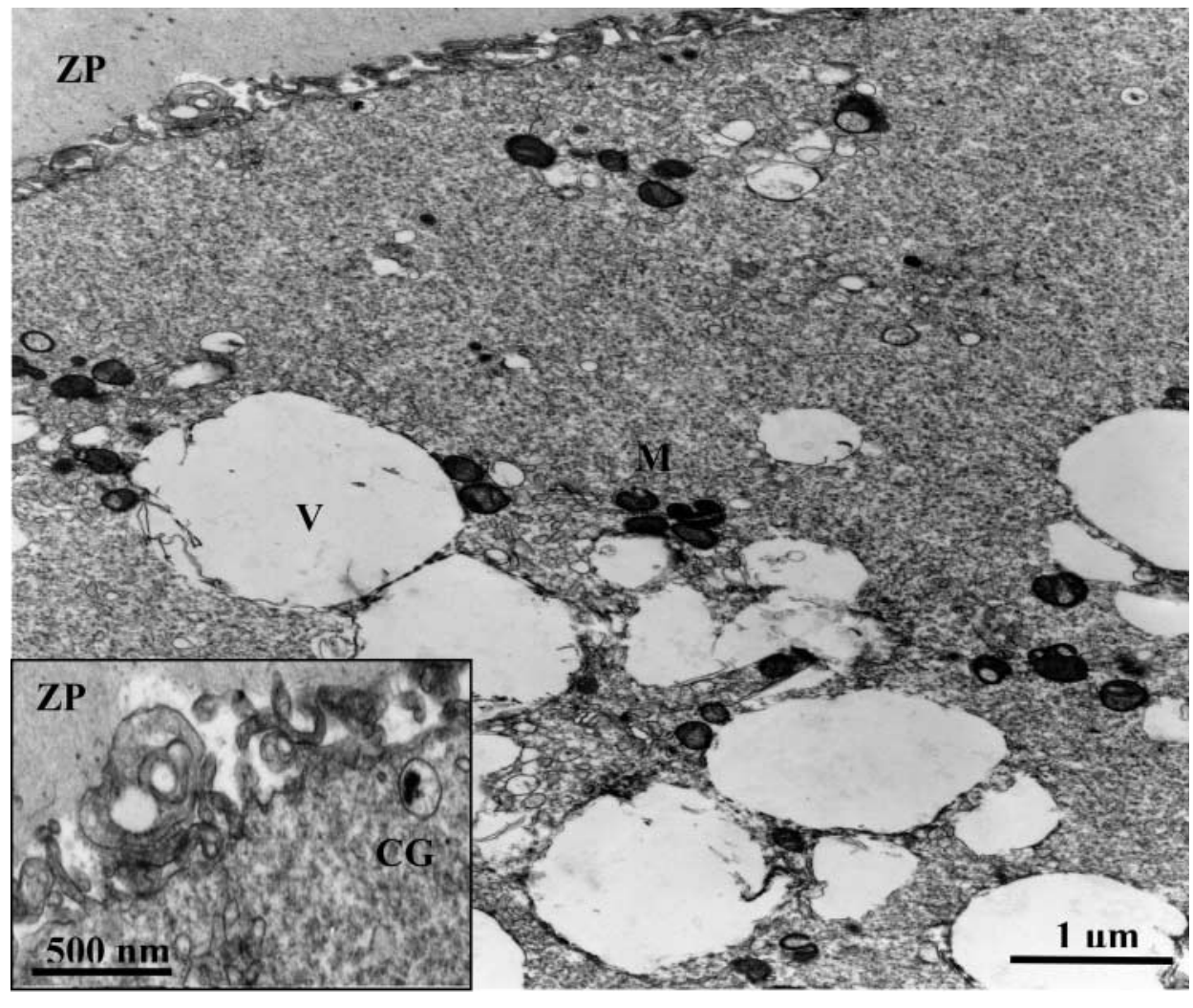

Figure 7 Electron micrograph showing part of an in vitro matured oocyte following follicle culture in the presence of insulin. Cortical granules (CG) are located individually in the margin of oocyte. Microvilli are disconnected and terminate in the perivitelline space (see inset). $V$, fat vesicle; $M$, mitochondria; $Z P$, zona pellucida. 
A

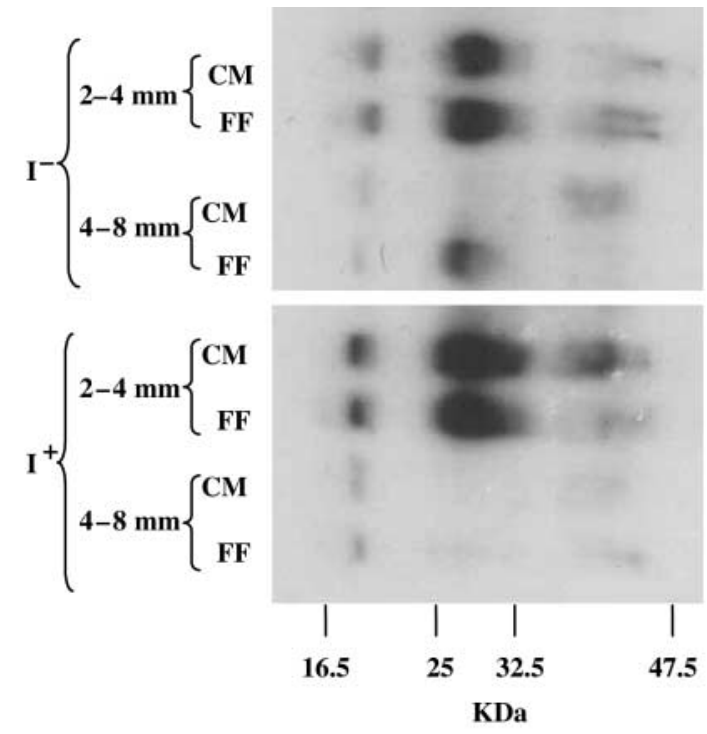

B

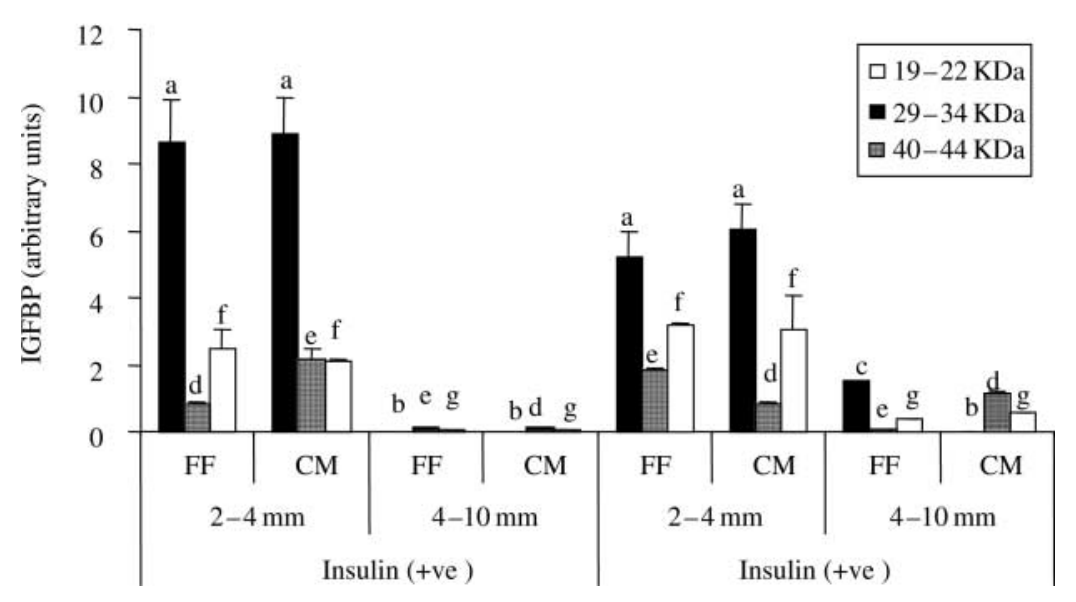

Figure 8 Effects of addition of insulin during culture of bovine antral follicle on the IGFBP profile. Follicles from two size ranges of small $(2-4 \mathrm{~mm})$ and medium $(4-8 \mathrm{~mm})$ were cultured in the presence $\left(\mathrm{I}^{+}\right)$ or absence of insulin $\left(\mathrm{I}^{-}\right)$. Follicular fluid (FF) and culture medium (CM) were collected from two size groups of follicle following $24 \mathrm{~h}$ of follicle culture. Controls, follicular fluid from directly aspirated follicles. a vs $\mathrm{b}, P<0.001$; $\mathrm{b}$ vs $\mathrm{c}, P<0.01$; a vs $\mathrm{c}$, $P<0.01 ; \mathrm{d}$ vs e, $P<0.05 ; \mathrm{f}$ vs $\mathrm{g}, P<0.01$. and that this stimulation of embryonic development was mediated through the IGF-I receptor. However, these authors did not report the frequency of development to the blastocyst stage. In the studies reported here, insulin at a concentration of $5 \mu \mathrm{g} / \mathrm{ml}$ was added to the follicle culture medium. This level of insulin, which is routinely used for the culture of preantral follicles, is greater than the physiological concentrations of insulin reported in biological fluids $(0.5-10 \mathrm{ng} / \mathrm{ml})$ (Diamond et al. 1985). However, although this high concentration of insulin resulted in a decrease in oocyte cleavage, the frequency of blastocyst production was not affected. In addition, the quality of blastocysts produced (as assessed by total cell number) was not significantly different between the two groups. In the present study, we have used Waymouth medium to culture follicles. Waymouth medium is extensively used for culture of follicles in different species. However, it contains a high concentration of glucose that may affect oocyte maturation. In oocytes, glucose is essential for optimal completion of nuclear maturation to metaphase II stage, but supraphysiological levels may be detrimental and compromise subsequent developmental capacity (Hashimoto et al. 2000). Exposure of mouse oocytes to diabetic conditions during folliculogenesis has a negative effect on meiotic maturation and subsequent development, due to decreased communication between the somatic and germ cell compartments (Colton et al. 2003). In the mouse, alterations in energy substrate supplementation profoundly influence meiotic regulation in vitro. For example, high glucose induces germinal vesicle breakdown in COCs in the presence of meiotic inhibitors (Downs \& Mastropolo 1994). In the present study, a lower cleavage rate was observed in oocytes derived from the insulin-treated group. It seems that insulin supplied a surplus amount of glucose for oocytes that resulted in an alteration of oocyte cytoplasmic maturation which adversely affected cleavage rate. However, no differences were observed in the developmental competence of oocytes as assessed by frequency of development to blastocyst stage and total cell numbers. Indeed, although not significant, slightly higher numbers of 
blastocysts were produced in oocytes derived from the insulin-treated follicle culture group. In addition, these blastocysts contained slightly increased total cell numbers than the oocytes from the insulin-negative group.

Any effects of the insulin family of growth factors on the oocyte in vivo are possibly regulated by IGFBPs (Funston et al. 1996). IGFBPs have a regulatory role in follicle development (Echternkamp et al. 1994) and are developmentally regulated in bovine granulosa and theca cells (Spicer \& Echternkamp 1995). IGFBP-2 and possibly IGFBP-4 and -5 are high in small- and medium-sized follicles, but reduce or become undetectable in large or dominant follicles, resulting in increased IGF bioactivity and enhancing the amplification of gonadotrophin action on follicular cells (Spicer \& Echternkamp 1995, Funston et al. 1996, de la Sota et al. 1996). In contrast, atresia is characterised by an increase in concentrations of the low molecular weight IGFBPs in the follicular fluid (Besnard et al. 1997).

The present study on the effects of insulin on IGFBPs in both culture media and follicular fluid indicate that in insulin-treated follicles of $>4 \mathrm{~mm}$ in diameter, two protein bands with estimated molecular weights of $19-22$ and 29-34 kDa corresponding to the low molecular weight IGFBP-4 and 2 were significantly reduced to undetectable levels. It is possible that this reduction of low molecular weight IGFBPs resulted in protection of larger follicles against atresia. However, in small follicles, insulin did not protect follicles against atresia, so the concentrations of IGFBPs increased. During follicular development in cattle, the IGFBP-3 content of follicular fluid increases (Armstrong et al. 1996). In addition, growth of follicles larger than $4 \mathrm{~mm}$ in diameter is FSH dependent (Gong et al. 1995). The presence of insulin may have a compensatory role in this group of follicles, resulting in healthier follicles. On the other hand, the disappearance of low molecular weight IGFBPs in larger follicles may be explained by intrinsic changes in the follicle and any effect of insulin on the follicle are ignored.

Analysis of the ultrastructure of the recovered oocytes showed that insulin-treated follicles yield oocytes which have features normally associated with matured oocytes. This may explain the reduced cleavage rate after fertilisation. As these oocytes were cultured in maturation medium for a further $24 \mathrm{~h}$, to allow nuclear maturation, the early occurrence of cytoplasmic changes may suggest that the oocytes became hypermature or aged, thus resulting in a lower fertilisation rate than the control group. In porcine (May \& Schomberg 1981), human (Hill \& Osteen 1992) and bovine (Spicer et al. 1993) ovarian tissue, insulin stimulates granulosa cell progesterone secretion, granulosa cell luteinisation (Channing et al. 1967) and induces granulosa cell LH/hCG receptors (Osteen et al. 1985, May \& Schomberg 1981). In the experiments presented here, the levels of progesterone were not compared between the two groups. If insulin supplementation increases progesterone level in the follicular fluid, then it may mimic the phenomenon at the preovulatory surge of $\mathrm{LH}$ that leads to resumption of meiosis in the oocytes.

In conclusion, follicle culture in the presence of insulin has no detrimental effect on oocyte structure and does not improve bovine oocyte quality or preimplantation embryo development in vitro, but appears to promote cytoplasmic maturation. In addition, the presence of insulin during follicle culture may prevent the process of atresia in medium-sized antral follicles.

\section{Acknowledgements}

The authors would like to thank Dr David Armstrong and Mrs C Hogg for IGFBP analysis. The authors declare that there is no conflict of interest that would prejudice the impartiality of this scientific work.

\section{References}

Armstrong DG, Hogg CO, Campbell BK \& Webb R 1996 Insulin-like growth factor (IGF)-binding protein production by primary cultures of ovine granulosa and theca cells. The effects of IGF-I, gonadotropin, and follicle size. Biology of Reproduction $\mathbf{5 5}$ $1163-1171$.

Armstrong DG, McEvoy TG, Baxter G, Robinson JJ, Hogg CO, Woad KJ, Webb R \& Sinclair KD 2001 Effect of dietary energy and protein on bovine follicular dynamics and embryo production in vitro: associations with the ovarian insulin-like growth factor system. Biology of Reproduction 64 1624-1632.

Armstrong DG, Gong J \& Webb R 2003 Interactions between nutrition and ovarian activity in cattle: physiological, cellular and molecular mechanisms. Reproduction 61 (Supplement) 403-414.

Besnard N, Pisselet C, Monniaux D \& Monget P 1997 Proteolytic activity degrading insulin-like growth factor-binding protein-2, -3 , -4 , and -5 in healthy growing and atretic follicles in the pig ovary. Biology of Reproduction 56 1050-1058.

Betteridge KJ, Smith C, Stubbings RB, Xu KP \& King WA 1989 Potential genetic improvement of cattle by fertilization of fetal oocytes in vitro. Journal of Reproduction and Fertility 38 (Supplement) $87-98$.

Blum F, Beier H \& Gross HJ 1987 Improved silver staining of plant proteins, RNA and DNA in polyacrylamide gels. Electrophoresis $\mathbf{8}$ 93-99.

Breslow NE \& Clayton DG 1993 Approximate inference in generalised linear mixed models. Journal of the American Statistics Association 88 9-25.

Campbell BK, Scaramuzzi RJ \& Webb R 1995 Control of antral follicle development and selection in sheep and cattle. Journal of Reproduction and Fertility 49 (Supplement) 335-350.

Chang AS, Dale AN \& Moley KH 2005 Maternal diabetes adversely affects preovulatory oocyte maturation, development, and granulose cell apoptosis. Endocrinology 146 2445-2453.

Channing CP, Tsai V \& Sachs D 1976 Role of insulin, thyroxine and cortisol in luteinisation of porcine granulosa cells grown in chemically defined media. Biology of Reproduction $15235-247$.

Chi MM, Schlein AL \& Moley KH 2000 High insulin-like growth factor 1 (IGF-1) and insulin concentrations trigger apoptosis in the mouse blastocyst via down-regulation of the IGF-1 receptor. Endocrinology 141 4784-4792.

Cicirelli MF, Pelech SL \& Krebs EG 1988 Activation of multiple protein kinases during the burst in protein phosphorylation that precedes the first meiotic cell division in Xenopus oocytes. Journal of Biological Chemistry $2632009-2019$.

Colton SA, Humpherson PG, Leese HJ \& Downs SM 2003 Physiological changes in oocyte-cumulus cell complexes from diabetic 
mice that potentially influence meiotic regulation. Biology of Reproduction $69761-770$.

Davoren JB \& Hsueh AJW 1984 Insulin enhances FSH-stimulated steroidogenesis by cultured rat granulosa cells. Molecular and Cellular Endocrinology 35 97-105.

Diamond MP, Webster BW, Carr RK, Wentz AC \& Osteen KG 1985 Human follicular fluid insulin concentrations. Journal of Clinical Endocrinology and Metabolism 61 990-992.

Downs SM \& Mastropolo AM 1994 The participation of energy substrates in the control of meiotic maturation in murine oocytes. Developmental Biology 162 154-168.

Duleba AJ, Spaczynski RZ, Olive DL \& Behrman HR 1997 Effects of insulin and insulin-like growth factors on proliferation of rat ovarian theca-interstitial cells. Biology of Reproduction $\mathbf{5 6}$ 891-897.

Dumesic DA, Schramm RD \& Abbott DH 2005 Early origins of polycystic ovary syndrome. Reproduction, Fertility and Development 17 349-360.

Echternkamp SE, Howard HJ, Roberts AJ, Grizzle J \& Wise T 1994 Relationships among concentrations of steroids, insulin-like growth factor-I, and insulin-like growth factor binding proteins in ovarian follicular fluid of beef cattle. Biology of Reproduction 51 971-981.

Fouladi-Nashta AA, Waddington D \& Campbell KHS 1998 Maintenance of bovine oocytes in meiotic arrest and subsequent development in vitro. A comparative evaluation of antral follicle culture with other methods. Biology of Reproduction $\mathbf{5 9}$ $255-262$.

Fulghesu AM, Villa P, Pavona V, Guido M, Apa R, Carusa A, Lanzone A, Rossodivita A \& Mancuso S 1997 The impact of insulin secretion on the ovarian response to exogenous gonadotropins in polycystic ovary syndrome. Journal of Clinical Endocrinology and Metabolism 82 644-648.

Funston RN, Seidel GE Jr, Klindt J \& Roberts AJ 1996 Insulin-like growth factor I and insulin-like growth factor-binding proteins in bovine serum and follicular fluid before and after the preovulatory surge of luteinizing hormone. Biology of Reproduction $\mathbf{5 5}$ 1390-1396.

Gong JG, Bramley TA \& Webb R 1993a The effect of recombinant bovine somatotrophin on ovarian follicular growth and development in heifers. Journal of Reproduction and Fertility 97 247-254.

Gong JG, Bramley TA, Wilmut I \& Webb R 1993b Effect of recombinant bovine somatotropin on superovulatory response to pregnant mare serum gonadotrophin in heifers. Biology of Reproduction 48 $1141-1149$.

Gong JG, Bramley TA, Gutierrez CG, Peters AR \& Webb R 1995 Effects of chronic treatment with a gonadotrophin-releasing hormone agonist on peripheral concentrations of FSH and $\mathrm{LH}$, and ovarian function in heifers. Journal of Reproduction and Fertility $105263-270$

Harvey MB \& Kaye PL 1988 Insulin stimulates protein synthesis in compacted mouse embryos. Endocrinology 122 1182-1184.

Hashimoto S, Minami N, Yamada M \& Imai H 2000 Excessive concentration of glucose during in vitro maturation impairs the developmental competence of bovine oocytes after in vitro fertilization: relevance to intracellular reactive oxygen species and glutathione contents. Molecular Reproduction and Development $\mathbf{5 6}$ 520-526.

Hill GA \& Osteen KG 1992 The effect of insulin on in vitro progesterone production of human granulosa cells. International Journal of Fertility 37 93-98.

Hsueh AJW, Adashi EY, Jones PBC \& Welsh TH Jr 1984 Hormonal regulators of the differentiation of cultured ovarian granulosa cells. Endocrine Reviews 5 76-127.

Hyttel P \& Madsen I 1987 Rapid method to prepare mammalian oocytes and embryos for transmission electron microscopy. Acta Anatomica 129 12-14.

Jones JI \& Clemmons DR 1995 Insulin-like growth factors and their binding proteins: biological actions. Endocine Reviews 16 3-34.
Kaye PL, Bell KL, Beebe LFS, Dunglison GF, Gardner HG \& Harvey MB 1992 Insulin and the insulin-like growth factors (IGFs) in preimplantation development. Reproduction, Fertility and Development 4 373-386.

Kruip TA \& Dieleman SJ 1982 Macroscopic classification of bovine follicles and its validation by micromorphological and steroid biochemical procedures. Reproduction, Nutrition, Development 22 465-473.

Lessman CA \& Schuetz AW 1981 Role of follicle wall in meiosis reinitiation induced by insulin in Rana pipiens oocytes. American Journal of Physiology 241 E51-E56.

Mason HD, Willis D, Holly JM, Cwyfan-Hughes SC, Seppala M \& Franks S 1992 Inhibitory effects of insulin-like growth factor-binding proteins on steroidogenesis by human granulosa cells in culture. Molecular and Cellular Endocrinology 89 R1-R4.

Matsui M, Takahashi Y, Hishinuma A \& Kanagawa H 1997 Stimulation of the development of bovine embryos by insulin and insulin-like growth factor-I (IGF-I) is mediated through the IGF-I receptor. Theriogenology 48 605-616.

May JV \& Schomberg DW 1981 Granulosa cell differentiation in vitro: effect of insulin on growth and functional integrity. Biology of Reproduction 25 421-431.

May JV, McCarty K Jr, Reichert LE Jr \& Schomberg DW 1980 Follicle stimulating hormone mediated induction of functional luteinisating hormone/human chorionic gonadotrophin receptors during monolayer culture of porcine granulosa cells. Endocrinology 107 1041-1049.

Monget P, Monniaux D, Pisselet C \& Durand P 1993 Changes in insulin-like growth factor-I (IGF-I), IGF-II, and their binding proteins during growth and atresia of ovine ovarian follicles. Endocrinology 132 1438-1446.

Moor RM, Hay MF, McIntosh JEA \& Caldwell BV 1973 Effect of gonadotrophins on the production of steroids by sheep ovarian follicles cultured in vitro. Journal of Endocrinology 58 599-611.

Mutter GL, Grills GS \& Wolgemuth DJ 1988 Evidence for the involvement of the proto-oncogene c-mos in mammalian meiotic maturation and possibly very early embryogenesis. EMBO Journal 7 683-689.

Naz RK, Leslie MH \& Zhu X 2001 Inhibition of murine spermoolemma binding by antibodies to an oocyte membrane (OM) antigen: implication in contraceptive vaccine development. American Journal of Reproductive Immunology 45 52-61.

Osteen KG, Anderson LD, Reichert LE \& Channing CP 1985 Follicular fluid modulation of functional $\mathrm{LH}$ receptor induction in pig granulosa cells. Journal of Reproduction and Fertility $\mathbf{7 4}$ 407-418.

Poretsky L 1991 On the paradox of insulin-induced hyperandrogenism in insulin-resistant states. Endocrine Reviews 12 3-13.

Poretsky L \& Kalin MF 1987 The gonadotrophic function of insulin. Endocrine Reviews 8 132-141.

Rao LV, Wikarczuk ML \& Heyner S 1990 Functional roles of insulin and insulin like growth factors in preimplantation mouse embryo development. In Vitro Cellular and Developmental Biology 26 $1043-1048$.

Reynolds ES 1963 The use of lead citrate at high $\mathrm{pH}$ as an electronopaque stain in electron microscopy. Journal of Cell Biology 17 $208-212$.

Schultz GA, Hogan A, Watson AJ, Smith RM \& Heyner S 1992 Insulin, insulin-like growth factors and glucose transporters: temporal patterns of gene expression in early murine and bovine embryos. Reproduction, Fertility and Development 4 361-371.

de la Sota RL, Simmen FA, Diaz T \& Thatcher WW 1996 Insulin-like growth factor system in bovine first-wave dominant and subordinate follicles. Biology of Reproduction 55 803-812.

Spicer LJ, Alpizar A \& Echternkamp SE 1993 Effects of insulin, insulin-like growth factor I, and gonadotrophins on bovine granulosa cell proliferation, progesterone production, oestradiol production, and (or) insulin-like growth factor-I production in vitro. Journal of Animal Science 71 1232-1241. 
Spicer LJ \& Echternkamp SE 1995 The ovarian insulin and insulinlike growth factor system with an emphasis on domestic animals. Domestic Animal Endocrinology 12 223-245.

Straus DS 1981 Effects of insulin on cellular growth and proliferation. Life Science $292131-2139$.

Stubbings RB, Liptrap RM, Betteridge KJ, Walton JS, Armstrong DJ \& Basrur PK 1990 Requirements for bovine oocyte maturation in vitro. Reproduction in Domestic Animals 25 158-166.

Thompson JGD, Simpson AC, Paugh PA, Wright RW \& Tervit HR 1991 Glucose utilisation by sheep embryos derived in vivo and in vitro. Reproduction, Fertility and Development 3 571-576.

Tsafriri A \& Channing CP 1975 Influence of follicular maturation and culture conditions on the meiosis of pig oocytes in vitro. Journal of Reproduction and Fertility 43 149-152.

Tulppala M, Stenman UH, Cacciatore B \& Ylikorkala O 1993 Polycystic ovaries and levels of gonadotrophins and androgens in recurrent miscarriage: prospective study in 50 women. British Journal of Obstetrics and Gynaecology 1993100 $348-352$
Watson AJ, Watson PH, Arcellana-Panlilio M, Warnes D, Ealker SK Schultz GA, Armstrong DT \& Seamark RF 1994 A growth factor phenotype map for ovine preimplantation development. Biology of Reproduction 50 725-733.

Watson ML 1958 Staining of tissue sections for electron microscopy with heavy metals. Journal of Biophysics and Biochemical Cytology 4 475-478.

Zephne M, vanderSpuy \& Dyer SJ 2004 The pathogenesis of infertility and early pregnancy loss in polycystic ovary syndrome. Best Practice and Research in Clinical Obstetrics and Gynaecology 18 755-771.

Received 24 November 2004

First decision 3 February 2005

Revised manuscript received 19 August 2005

Accepted 22 November 2005 